\title{
OVERT AND CRYPTIC STRONGLY POTASSIC MAFIC LIQUIDS IN THE NEOGENE MAGMATISM OF THE NORTHERNMOST PART OF THE RIO GRANDE RIFT, U.S.A.: A LITHOSPHERIC DRIP-FEED INTO A ASTHENOSPHERIC-SOURCE MAGMAS?
}

\author{
Thompson, ${ }^{(1)}$ R.N.; Gibson ${ }^{(1)}$, S.A. and Leat, ${ }^{(2)}$ P.T.
}

(1) Dept. of Geological Sciences, University of Durham, South Road, Durham, DH1 3LE, U.K.; (2) British Antarctic Survey, High Cross, Madingley Road, Cambridge, CB3 OET, U.K.

At present the Rio Grande rift extends as a physiographic feature for about $700 \mathrm{~km}$ from near the Mexico/USA border to a northern terminus near Leadville, colorado. From the time of its initiation, at about $25 \mathrm{Ma}$, until as recently as 5 Ma there was a northward prolongation of the rift between approximately Aspen, NW Colorado, and the Colorado/wyoming border. The extension in this northernmost rift segment was distributed amongst several sub-parallel graben, as in the southernmost part of the rift. As elsewhere within both the rift and other parts of the Basin and Range structural province, the extension and related magmatism in NW colorado was mostly concentrated into two phases: between about 25 and $20 \mathrm{Ma}$, and between about 13 and $5 \mathrm{Ma}$. Whilst the second tectonomagmatic phase continues to the present in the southern Rio Grande rift, the northernmost segment was uplifted substantially and ceased to extend at about $5 \mathrm{Ma}$. At that time the yellowstone mantle plume is thought first to have approached this area, although still hundreds of $\mathrm{km}$ to the $\mathrm{NW}$, and a component of this abrupt uplift may have been dynamic elevation above the plume head. Extension began only a few Ma after the initiation of the san Andreas fault system and it is generally supposed that Nw colorado was underlain by subducted fragments of the Farallon lithospheric plate until at least as recently as $10 \mathrm{Ma}$. Between about 25 and $10 \mathrm{Ma}$ the predominant magmas extruded in this area were basalts with elemental characteristics resembling those of oceanic subduction-related melts; mostly calcalkaline, with subordinate absarokites and shoshonites. The first liquids to appear with the elemental and isotopic characteristics of ocean-island magmatism (OIB) were basanites at Yampa, at about $5.5 \mathrm{Ma}$.

Very sparse strongly potassic lavas and hypabyssal plutons accompanied the basalts throughout this region. These are: (1) Minette ( $-24 \mathrm{Ma})$ at Middle Park; (2) Minette dykes and sills ( 10 Ma) throughout the Elkhead Mts; (3) Minette dykes ( $-5.5 \mathrm{Ma}$ ) at Yampa; (4) Lamproite lavas ( $1 \mathrm{Ma}$ ) at Leucite Hills, $150 \mathrm{~km}$ NW of the Elkhead Mts. The Leucite Hills magmatism is logically regarded as part of the $\mathrm{NW}$ colorado province; it is little further from the centre of that region than the Grand Mesa basalts to the south. Incompatible element abundances in examples from each of these four occurrences are sumnarised in Fig. 1. It is clear that, although they were all erupted or emplaced within a relatively small area, these strongly potassic magmas were very variable in composition. The Middle Park minette and Leucite Hills lavas have similar compositions but they are both different from the Elkhead Mts and Yampa minettes. Igotopically, these rocks all show the combination of relatively low Sr/ ${ }^{86}$ and very low end that characterises magmas thought to originate from EMI lithospheric mantle, or at least to contain a large fraction from such a source. Nevertheless, judging from the surface geology, most of the NW colorado igneous province is definitely not sited on the Archaean Wyoming craton. Its southern boundary, the cheyenne belt, passes just north of the Elkhead Mts and the oldest radiometric ages throughout NW colorado are $\sim 1.8 \mathrm{Ga}$. 
In addition to the overt strongly potassic magmatism listed above, there are other occurrences in NW colorado where a good case can be made that a strongly potassic mafic liquid was a sporadic major additive to predominantly basaltic liquids. The best examples for showing this phenomenon are the dykes and volcanic necks at Yampa, and flow-by-flow chemical studies of lava successions at Yarmony Mt. and Flat Tops. The contrasting incompatible element abundances and ratios of the extreme compositions amongst the Yampa alkalic rocks, a minette and a basanite resembling those of ocean islands (with oIB-like radiogenic isotope ratios), are shown on Fig. 2. Once corrected for fractional crystallisation, the compositions of the other Yampa samples fall between these extremes. On Yarmony Mt. a succession of 11 basaltic lavas ( 24 Ma) is preserved. Flow number 7 from the base has similar major elements to the others, apart from slightly higher sio, But it is, dramatically relatively enriched in such incompatible elements as $\mathrm{K}, \mathrm{Ba}, \mathrm{Th}, \mathrm{La}$ and $\mathrm{zr}$. Both the elemental and isotopic differences between this and the other flows fit a model in which this particular magma batch was contaminated by 10-208 of strongly potassic mafic melt from an old lithospheric mantle source. The Flander section of the contemporaneous Flat Tops lavas provides two more examples of this phenomenon, showing subtle differences from the Yarmony Mt case. Thirty consecutive (24-20 Ma) flows at Flander can be divided into several groups with secular geochemical variations that are consistent with models of open-system fractional crystallisation, together with a small concomitant input from assimilated proterozoic upper crust. In addition, two anomalous $\mathrm{k}$-rich flows occur (one low and one high in the section) which have incompatible abundances and ratios that cannot be attributed to any plausible crustal contaminant. A strong case can be made from elemental evidence that these two magma batches contain substantial fractions of strongly potassic mafic melt. The very $84^{n u s y a l}$ feature of the Flander K-rich lavas is they have somewhat lower $87 \mathrm{sr} /{ }^{86} \mathrm{Sr}$ and higher $143{ }^{14}$ Nd than other flows in the section. Therefore, if the strongly potassic component was present in the form of local

incompatible-element enrichment in the lithospheric mantle, before Lower Miocene stretching and heating, it can only have existed for a geologically short period of time.

Taken as a whole, these studies give a consistent picture of the magmatic reponse of a region with relatively thick lithosphere to stretching and heating from below. Detailed geophysical data on the lithosphere thickness in NW colorado are lacking but the nearby state Iine area, along the Front Range in northern colorado, yielded diamondiferous kimberlites in the Devonian. The very close associations of strongly potassic mafic melts with basalts throughout the area (except the Leucite Hills) suggest that heat advected into the sub-continental lithospheric mantle by basic magmas originating deeper may have caused local melting of the most-easily-fusible parts of the lithosphere. The elemental and isotopic compositions of the strongly potassic mafic liquids - both those . forming separate magma batches and those occurring as components of mixtures - show substantial variability in the composition of this fraction of the lithospheric upper mantle beneath NW colorado and SW Wyoming, on a scale of tens of $\mathrm{km}$. The age of the process that gave rise to the sources of the strongly potassic magmas also appears to have varied between the age of the lithosphere $(-1.8 \mathrm{Ga})$ and as little as Mesozoic. Turning to the predominant basalts of the region, the only ones that can be ascribed to asthenospheric sources without reservations are the oIB-like Yampa basanites. The broadly calcalkaline "subduction-related" geochemical features of the older basalts are most simply explained by postulating that they originated in asthenospheric mantle that was chemically modified by melts and/or fluids released from underlying slabs of subducted Farallon plate. Nevertheless, the distinctive chemical features of these basalts are far from unique and it is difficult to determine with complete certainty the relative amounts of components with lithospheric and asthenospheric sources in them. 


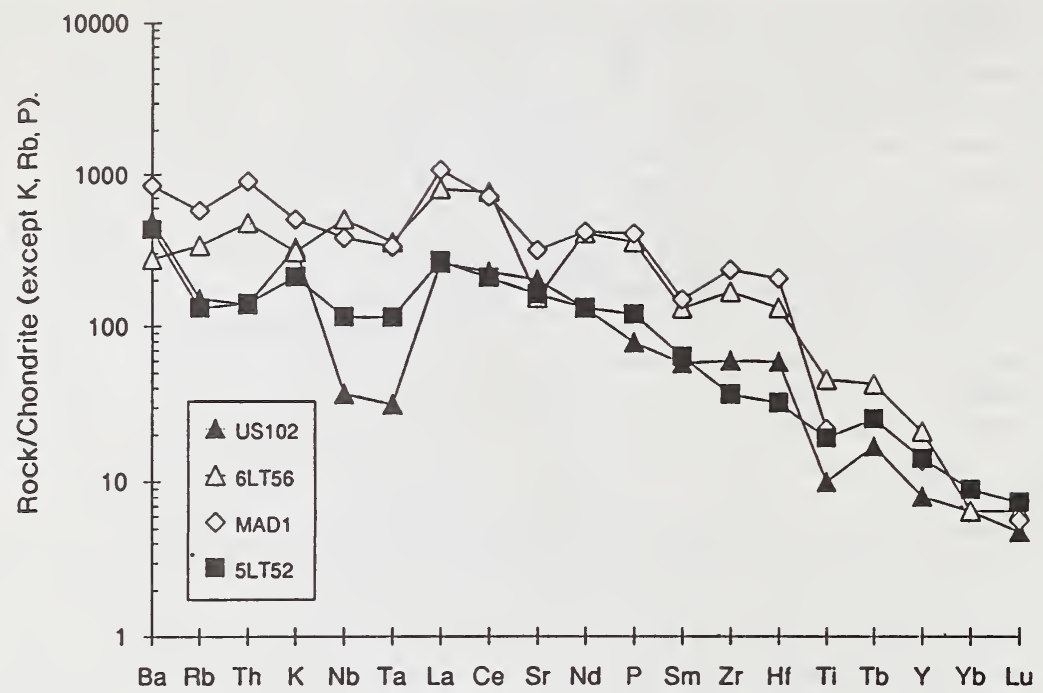

Fig. 1. Comparison of incompatible trace element abundances and ratios in four Neogene occurrences of strongly potassic mafic magmatism in NW Colorado and southern wyoming. Localities are: US102, Elkhead Mts; 6LT56, Middle Park; MAD1, Leucite Hills; 5LT52, Yampa. See text for details.

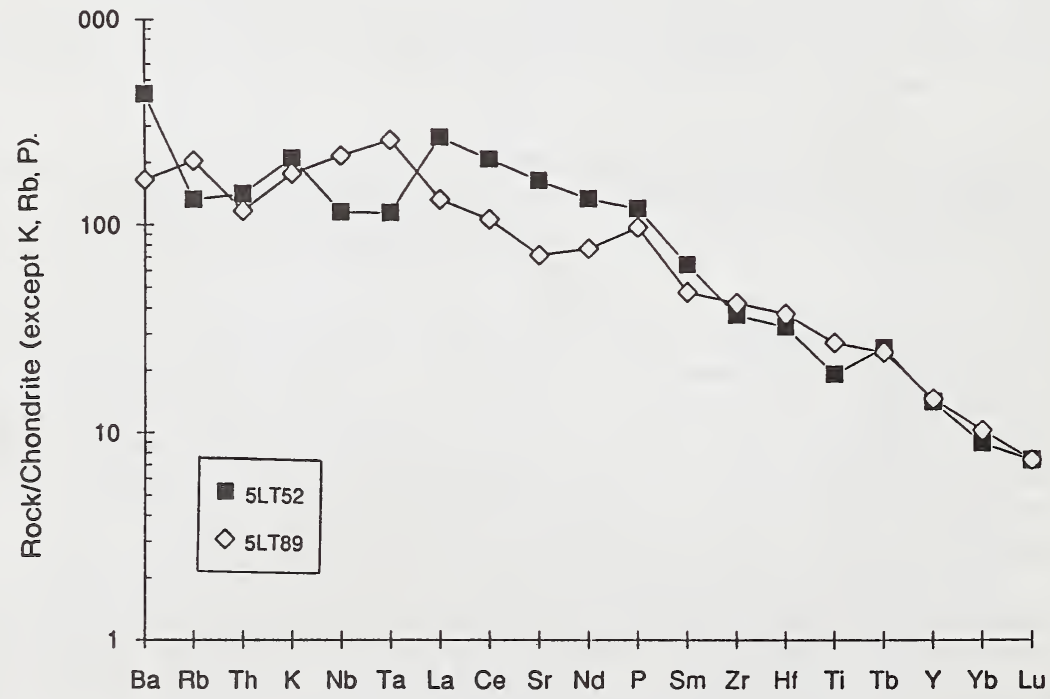

Fig. 2. Comparison of incompatible trace element abundances and ratios in the extreme mafic magma compositions of the Yampa igneous field, NW colorado. 5LT52, minette; 5LT89, OIB-like basanite. 